\title{
PERAN ORANG TUA DALAM MEMBENTUK KARAKTER ANAK DI ERA GLOBALISASI DI DESA MASIGIT KELURAHAN CITANGKIL KOTA CILEGON
}

\author{
Fitria Nuraini $^{1}$, Toni Anwar Mahmud ${ }^{2}$ \\ Universitas Banten Jaya \\ Serang, Indonesia \\ fnuraini54@gmail.com ${ }^{1,}$ toniam@unbaja.ac.id ${ }^{2}$
}

\begin{abstract}
The title of the research is The Role of Parents in Shaping the Character of Children in the Globalization Era in Masigit Village, Citangkil Village, Cilegon City. In the current era of globalization, there are many influences, both positive and negative. This negative influence must be avoided because it can affect a person's habits, attitudes, and behavior. Character education is one of the important things that must be applied in the family environment. Parents must reflect good attitudes and habits in interacting in the family environment and in the community environment. This is important for fostering good attitudes and habits in children. The formulation of the problem in this study is how the role of parents in improving children's character in the era of globalization, Masigit Village, Citangkil Village, Cilegon City. What factors can influence the formation of children's character in the era of globalization, Masigit Village, Citangkil Village, Cilegon City. What efforts are made by parents in shaping children's character in the era of globalization in Masigit Village, Citangkil Village, Cilegon City. This study aims to determine the role of parents in shaping children's character in the era of globalization in Masigit Village, Citangkil Village, Cilegon City. The subjects of this study were 6 parents and 6 children in Masigit Village, Citangkil Village, Cilegon City. This research uses descriptive qualitative research methods. Data analysis in qualitative research is by doing data reduction, data presentation, and data verification. The results of this study indicate that the role of parents in Masigit Village, Citangkil Village, Cilegon City has been good in shaping children's character in the era of globalization.
\end{abstract}

Keywords: Role of Parents, Forming Character, Globalization Era

\section{PENDAHULUAN}

Pendidikan merupakan tolak ukur yang dapat menuntaskan segala macam permasalahan dalam setiap kehidupan manusia. Pendidikan merupakan arah, pondasi yang menentukan setiap individu menjadi lebih bermakna dalam hidupnya. Sesuai yang dijelaskan oleh (Prianti:2019) bahwa pendidikan adalah proses pematangan kualitas hidup dalam meningkatkan kualitas sumber daya manusia (SDM) sehingga dalam proses pendidikan setiap manusia mampu memahami arti hakikat kehidupan yang sebenarnya secara benar. Hal tersebut dijelaskan pula dalam Undang-Undang Nomor 20 Tahun 2003 Tentang Sistem Pendidikan Nasional bahwa pendidikan ditujukan untuk mewujudkan proses pembelajaran agar peserta didik secara aktif mengembangkan potensi diri, kepribadian, kecerdasan, akhlak keterampilan, yang diperlukan oleh bangsa dan Negara. Jadi jelas bahwa pendidikan secara inti adalah proses untuk meningkatkan kualitas hidup manusia. Mutu pendidikan tidak terlepas dari faktor yang 
mempengaruhinya, tentu pendidikan tidak mampu berdiri sendiri tanpa keterlibatan hal lain sebagai penggerak dan pendukungnya. Faktor yang dimaksud adalah keluarga, sekolah maupun lingkungan masyarakat. Sebagaimana yang dijelaskan oleh (Baharudin:2010) bahwa ada tiga faktor yang berhubungan dengan pelaksanaan pendidikan diantaranya adalah lingkungan keluarga, lingkungan sekolah, dan lingkungan masyarakat. Salah satu dari ketiga faktor tersebut yang paling mendominasi pendidikan anak adalah keluarga.

Dapat dipastikan setiap orangtua sepenuhnya tidak mengharapkan kegagalan bagi anaknya. Dapat dipahami bahwa pendidikan dalam keluarga memiliki peran yang sangat penting yang menjadi dasar bagi pembentukan kepribadian anak, baik dalam pemberian pendidikan, bimbingan, serta memberikan pelatihan sesuai dengan nilai dan norma-norma untuk mempersiapkan anak agar dimasa yang akan datang dapat hidup dengan layak (Prianti:2019).

Keluarga merupakan suatu lingkungan sosial terkecil yang memiliki peran penting dalam pembentukan karakter seorang anak. Jika pendidikan karakter yang terapkan dalam keluarga baik, akan berpengaruh baik terhadap lingkungannya. Tetapi, jika pendidikan karakter yang diterapkan dalam keluarga tidak baik, maka akan berpengaruh luas kepada lingkungannya. W.A. Gerungan dalam (Syarbini : 2016) berpandangan, keluarga merupakan kelompok sosial pertama dalam kehidupan manusia. Dalam keluarga awal pembentukkan dan perkembangan sosial manusia termasuk pembentukan norma sosial, interaksi sosial, frame of reference, sense of belongingness, dan lainnya. Lingkungan keluarga merupakan tempat dimana seorang anak berinteraksi untuk pertama kalinya. Maka pendidikan tidak hanya dapat dijalankan di sekolah saja, melainkan di rumah dengan bimbingan orangtua.

Karakter menurut Tadzkirotun Musfiroh dalam (Syarbini:2016) mendefinisikan karakter dengan serangkaian sikap (attitudes), perilaku (behaviors), motivasi (motivations), dan keterampilan (skills). Kuatnya pengaruh lingkungan keluarga terhadap pembentukan anak diungkap oleh Papini dalam (Syarbini:2014) bahwa peran penting dan kualitas keluarga yang ikut mewarnai pembentukan karakter antara lain terletak pada model pendidikan yang diberikan orang tua terhadap anaknya.

Pendidikan karakter seharusnya dimulai dari dalam keluarga, yang merupakan lingkungan pertama dan utama bagi pembentukan karakter anak. Hal itu disebabkan keluarga merupakan lingkungan tumbuh dan berkembang anak sejak mulai usia dini hingga mereka menjadi dewasa. Melalui pendidikan karakter dalam keluarga karakter seorang anak akan terbentuk. 
Menurut Megawangi dalam (Masnur Muslich : 2011), anak-anak akan tumbuh menjadi pribadi yang berkarakter apabila dapat tumbuh pada lingkungan yang berkarakter sehingga fitrah setiap anak yang dilahirkan suci dapat berkembang segera optimal. Mengingat lingkungan anak bukan saja lingkungan keluarga yang sifatnya mikro maka semua pihak, keluarga, sekolah, media massa, komunitas bisnis, dan sebagainya, turut andil dalam perkembangan karakter anak.

Kemajuan ilmu pengetahuan dan teknologi (IPTEK) tidak hanya memberikan dampak positif, namun juga memberikan dampak negatif bagi setiap kalangan dan lapisan masyarakat. Terlebih lagi pada saat ini banyak sekali masyarakat yang bergantung dengan gedget, bahkan anakanak saat ini pun banyak yang memilih bermain handphone dibandingkan berinteraksi dengan teman sebayanya. Hal ini tentunya harus menjadi perhatiam orangtua dalam penggunaan handphone.

Pendidikan karakter merupakan salah satu hal penting yang harus diterapkan dalam lingkungan keluarga. Orang tua sebagai role model bagi anak harus mencerminkan sikap dan kebiasaan yang baik dalam berinteraksi di lingkungan keluarga maupun dalam lingkungan masyarakat. Orang tua maupun anggota keluarga lainnya pun harus senantiasa bekerja sama dalam memberikan arahan kepada anak. Hal ini penting untuk menumbuhkan sikap dan kebiasaan yang baik dalam diri anak. Karena dari sikap yang ditunjukkan anak ini akan membentuk suatu kepribadian yang akan melekat dalam diri anak, serta akan diimplementasikan dalam lingkungan masyarakat.

Data penduduk Kota Cilegon tahun 2019 sebanyak 437.205 (Toni Anwar Mahmud: 2020:36. Kota Cilegon sebagai daerah industri tentunya akan menarik pendatang untuk meningkatkan taraf ekonominya di Kota Cilegon didukung oleh era globalisasi saat ini banyak sekali pengaruh yang datang, baik itu pengaruh yang positif dan negatif. Pengaruh negatif inilah yang harus dihindari, karena dapat mempengaruhi kebiasaan, sikap, dan tingkah laku seseorang. Berdasarkan hasil observasi pendahuluan peneliti dengan beberapa para orang tua di Kampung Masigit Kota Cilegon, anak-anak saat ini lebih menyukai bermain dengan handphone, sehingga anak-anak lalai akan tugas sekolah, beribadah, anak juga sering membantah perkataan orang tua. Dari adanya kemudahan dalam mengakses informasi mengakibatkan banyak hal yang dapat anak ketahui. Bahkan, hal-hal negatif sering kali muncul ketika anak mengakses internet seperti video-video, foto-foto yang tidak pantas, gaya berpakaian yang tidak sesuai, informasi yang dapat mempengaruhi psikis anak dan lain sebagainya. Karena penggunaan handphone ini juga sikap seorang anak cenderung menjadi 
individualis, berkurangnya rasa tanggung jawab dan disiplin pada diri anak.

Dampak yang ditimbulkan dari adanya globalisasi berdasarkan observasi dan wawancara yaitu dapat mempengaruhi sikap anak dalam lingkungan sehari harinya. Dalam lingkungan keluarga sikap anak berubah menjadi lebih malas, membantah kepada orang tua ketika orangtua menyuruh anak untuk membantu kegiatan di rumah bahkan malas untuk melakukan ibadah dan belajar. Dalam lingkungan sosial di kalangan teman sebayanya baik di sekolah maupun di lingkungan tempat tinggal anak cenderung bersikap acuh terhadap temannya. Komunikasi langsung yang dilakukan oleh seorang anak kepada temannya pun kurang terjalin dengan baik. Kurangnya rasa empati dan simpati anak terhadap sesama.

\section{METODE PENELITIAN}

Penelitian ini dilaksanakan di Desa Masigit Kelurahan Citangkil Kota Cilegon. Adapun waktu penelitian akan dilaksanaka pada tanggal 29 April 2020 sampai dengan 5 Juni 2020. Partisipan dalam penelitian ini yaitu Masyarakat khususnya orang tua, dan anak di desa Masigit Kelurauhan Citangkil Kota Cilegon. Pendekatan yang digunakan dalam penelitian ini adalah pendekatan kualitatif yaitu prosedur penelitian yang menggambarkan suatu keadaan dan gejala yang ada pada objek yang akan diteliti. Sesuai yang dijelaskan oleh (Sugiyono:2016) bahwa penelitian kualitatif adalah penelitian yang menggambarkan, mendeskripsikan dengan apa yang dilihat, didengar, dirasakan, dan ditanyakan.

Penelitian kualitatif menurut Denzin dan Lincoln dalam (Lexy J Moleong : 2014) adalah penelitian yang menggunakan latar alamiah, dengan maksud menafsirkan fenomena yang terjadi dan dilakukan dengan jalan melibatkan berbagai metode yang ada. Dari segi pengertian, para penulis masih tetap mempersoalkan latar alamiah dengan maksud agar hasilnya dapat digunakan untuk menafsirkan fenomena dan dimanfaatkan untuk penelitian kualitatif adalah berbagai macam metode penelitian. Dalam penelitian kualitatif metode yang biasanya dimanfatkan adalah wawancara, pengamatan, dan pemanfaatan dokumen.

Sedangkan teknik pengumpulan data dalam penelitian ini berupa observasi, wawancara, dan dokumentasi. Observasi yaitu peneliti mengumpulkan data dengan melakukan penelitian langsung ke lokasi penelitian, dalam penelitian ini observasi dilakukan di Desa Masigit Kelurahan Citangkil Kota Cilegon. Seperti halnya yang di jelaskan oleh (Sugiyono:2016) bahwa observasi terstruktur dilakukan apabila peneliti sudah ada kepastian tentang variable yang akan diamati dengan menggunakan instrument penelitian yang telah teruji.

Wawancara dalam penelitian yaitu dengan mengajukan pertanyaan kepada 
orangtua dan anak. Pada orang tua wawancara ini dilakukan untuk mengetahui seberapa besar peran orang tua dalam membentuk karakter anak. Sedangkan kepada anak wawancara ini dilakukan untuk mengetahui pemahaman anak mengenai peran orang tua dalam membentuk karakter. Wawancara ini dilakukan langsung kepada orangtua dan anak mengenai peran orang tua dalam membentuk karakter anak di era globalisasi. Dalam hal ini peneliti akan mempertanyakan pertanyaan-pertanyaan yang sudah disediakan dan terstruktur yang kemudian diperdalam untuk memperoleh keterangan lebih lanjut sehingga jawaban yang diperoleh meliputi semua variabel dengan keterangan yang lengkap dan mendalam (Arikunto:2013).

Dokumentasi dalam penelitian ini yaitu dengan mengumpulkan data melalui dokumen-dokumen yang berkaitan dengan penelitian seperti arsip, buku-buku, gambargambar yang berkaitan dengan penelitian

Analisis data adalah proses mencari dan menyusun secara sistematis yang diperoleh oleh hasil wawancara, catatan lapangan, dan dokumentasi, dengan cara mengorganisasikan data ke dalam kategori, menjabarkan ke dalam unit-unit, melakukan sintesa, menyusun ke dalam pola, memilih mana yang penting dan yang akan dipelajari dan membuat kesimpulan sehingga mudah dipahami oleh diri sendiri maupun orang lain (Sugiyono : 2016).
Dalam penelitian ini penelilti akan menggunakan teknik analisis data kualitatif dari Miles dan Huberman dalam (Sugiyono :2016) yaitu "analysis as consisting of three flows activity: data reducing, data display, and drawing conclusion or verification. Artinya tiga tahapan yang akan dilakukan dalam menganalisis data kualitatif yaitu dengan menggunakan mereduksi data, menampilkan/penyajian data dan menggambarkan kesimpulan atau membuat verifikasi.

Reduksi data dapat dijelaskan bahwa proses pemilihan, pemusatan perhatian pada penyederhanaan, pengabstrakan dan transformasi data kasar yang muncul dari catatan-catatan tertulis yang ada di lapangan sehinggalaporan akhir lengkap tersusun. Penyajian data dapat dilakukan dalam bentuk uraian singkat, bagan, hubungan antar kategori, flowchart dan sejenisnya. Yang paling sring digunakan untuk penyajian data dalam penelitian kualitatif adalah dengan teks yang bersifat naratif (Sugiyono:2016). Dalam penelitian ini penyajian data dilakuakn dengan menggunakan teks naratif.

Selanjutnya dilakukan verifikasi data yang dapat diartikan sebagai penarikan kesimpulan kegiatan mencari arti, mencari keteraturan, pola-pola penjelasan, alur sebab akibat dan proposisi. Selain itu dapat diartikan sebagai penarikan kembali yang melintas dalam fikiran penganalisis selama penyimpulan. 
HASIL

PENELITIAN

DAN

PEMBAHASAN

Berdasarkan data hasil temuan dan analisis data dalam penelitian ini, maka peneliti akan membahas mengenai bagaimana peran orang tua dalam membentuk karakter anak, faktor apa saja yang dapat mempengaruhi pembentukan karakter dan upaya apa yang dapat dilakukan untuk membentuk karakter anak di era globalisasi Desa Masigit Kelurahan Citangkil Kota Cilegon. Sesuai dengan hasil penelitian diatas, pembahasan hasil penelitian tentang peran orang tua dalam membentuk karakter anak di era globalisasi di Desa Masigit Kelurahan Citangkil Kota Cilegon diperoleh berdasarkan hasil observasi, wawancara, dan dokumentasi. Selanjutnya dapat dijabarkan sebagai berikut :

1. Peran Orang tua Dalam Meningkatkan Karakter Anak Di Era Globalisasi Desa Masigit Kelurahan Citangkil Kota Cilegon

Peran orang tua sangatlah penting dalam pembentukan karakter anak, orang tua merupakan pendidik paling utama dan pertama bagi seorang anak. Orang tua sudah sepatutnya menerapkan pendidikan karakter yang dimulai sejak dini. Peran dan tanggung jawab yang dimiliki oleh orang tua adalah mendidik anak, mengajarkan anak, memberikan perhatian serta kasih sayang kepada anak. Orang tua merupakan orang pertama yang mengasuh, membesarkan, membimbing dan mendidik serta memiliki pengaruh yang besar terhadap pertumbuhan dan perkembangan anak. Lingkungan pertama yang dilalui anak adalah keluarga yang merupakan basis utama dalam memberikan pendidikan. Orang tua memiliki peranan penting dalam upaya pengembangan pribadi anak.

Berdasarkan hasil penelitian di Desa Masigit Kelurahan Citangkil terhadap orang tua menunjukkan bahwa orang tua telah melakukan perannya dengan baik dalam membentuk karakter anak. Karena berdasarkan hasil data melalui wawancara dan observasi menunjukkan bahwa orang tua telah melakukan perannya dengan mendidik, mengajarkan, membimbing anak mengenail nilai-nilai kebaikan. Orang tua juga berlaku baik kepada anak dan mengarahkan anak ketika anak melakukan suatu kesalahan. Berdasarkan hasil penelitian juga orangtua memiliki peran yang sangat penting terhadap pembentukan karakter anak. Orang tua bukan hanya memiliki tanggung jawab untuk mengurus segala kebutuhannya saja melainkan memberikan pendidikan kepada anak, baik pendidikan karakter, pengetahuan, keterampilan, serta aspek lainnya. 
Orang tua berperan untuk membina serta mendidik anaknya baik dalam pengembangan pengetahuannya maupun dalam pembentukan karakter anak. Selain itu juga orang tua berperan unuk melindungi anaknya, memberikan kasih sayang, perhatian, serta motivasi kepada anak. . Hal ini sesuai dengan Peran dan tanggung jawab orangtua yang harus dilaksanakan yaitu sebagai berikut (Syarbini : 2014) :

1) Memelihara dan membesarkan anak, ini adalah bentuk paling sederhana dari tanggung jawab orangtua dan merupakan dorongan alami untuk mempertahankan kelangsungan hidup manusia.

2) Melindungi dan menjamin kesehatan, baik jasmaniah maupun rohaniah dari gangguan penyakit dan dari penyelewengan kehidupan dari tujuan hidup yang sesuai dengan agama falsafah hidup yang dianutnya.

3) Memberi pengajaran dalam arti luas sehingga anak memperoleh peluang untuk memiliki pengetahuan dan kecakapan seluas dan setinggi mungkin yang dapat dicapainya.

4) Membahagiakan anak, baik didunia maupun akhirat sesuai dengan pandangan dan tujuan hidupnya.

Peran orang tua bukan hanya untuk merawat dan membesarkannya, mencukupi segala kebutuhannya.
Tetapi, orang tua memiliki tanggung jawab untuk mendidik dan membina anaknya dalam hal kebaikan. Orang tua selaku pendidik utama hendaknya selalu memberikan pendidikan yang baik kepada anaknya, sehingga anak dapat tumbuh dan berkembang menjadi pribadi yang berkarakter.

\section{Faktor Yang Dapat Mempengaruhi} Pembentukan Karakter Anak Di Era Globalisasi Desa Masigit Kelurahan Citangkil Kota Cilegon

Berdasarkan hasil penelitian terungkap bahwa terdapat faktor-faktor yang dapat mempengaruhi dalam pemmbentuk karakter anak yaitu faktor lingkungan. Dimana faktor lingkungan ini sangat mempengaruhi perkemabangan karekter dari seorang anak. Lingkungan sosial yang baik akan menumbuhkan karakter dan sikap yang baik pula dalam diri anak, namun apabila lingkungan tempat anak bersosialisasi kurang baik maka karakter yang terbentuk pun kurang baik. Lingkungan bermain anak memiliki pengaruh yang cukup besar, karena dalam lingkungan ini anak bermain dan bersosialisasi dengan teman sebayamya yang memiliki karakter yang berbeda yaitu ada yang meniliki karakter baik dan adapula yang kurang baik.

Hal ini serupa dengan yang dijelaskan oleh (Helmawati : 2017) yang 
menyatakan bahwa lingkungan berpengaruh dalam pembentukan karakter seorang individu. Selain lingkungan keluarga dan lingkungan sekolah, lingkungan masyarakat pun memiliki pengaruh yang besar bagi pengembangan karakter. Walaupun lingkungan keluarga dan sekolah anak di didik untuk memiliki karater baik, jika lingkungan masyarakat memiliki karakter buruk yang dominan, maka anak akan terpengaruh menjadi tidak baik pula.

Menurut Dumadi dalam (Prianti \& Laila : 2019) karakter adalah sebagai sifat seseorang yang dapat dibentuk, artinya karakter seseorang dapat berubah, kendati karakter mengandung unsur bawaan (potensi internal), yang setiap orang dapat berbeda. Namun, karakter amat dipengaruhi oleh faktor eksternal, yaitu keluarga, sekolah, lingkungan pergaulan.

Berdasarkan penelitian dapat diketahui bahwa anak-anak saat ini sangat mudah terpengaruh ole pola asuh yang diterapkan oleh orangtua juga sangat berpengaruh terhadap pembentukan karakter anak. Dalam mendidik anak, setiap orangtua memiliki caranya masing-masing dalam mendidik anak. Berdasarkan hasil penelitian cara mendidik anak merupakan salah satu faktor yang dapat mempengaruhi pembentukan karakter anak. Orang tua yang cenderung acuh dan kurang perhatian terhadap anak akan mempengaruhi perkembangan karakter anak. Orang tua yang bersikap kasar baik dalam perkataan ataupun secara fisik akan mempengaruhi pula perkembangan karakter anak. Orang tua yang tidak memberikan perhatian yang lebih terhadap anak dan kurang menunjukkan rasa kasih sayang akan berdampak buruk bagi perkembangan karakter anak.

Menurut Megawangi yang dikemukakan dalam (Syarbini:2016) ada beberapa kesalahan orangtua dalam mendidik anak yang dapat memperngaruhi perkembangan kecerdasan emosi anak sehingga berakibat pada pembentukan karakternya, yaitu sebagai berikut :

1. Kurang menunjukkan ekspresi kasih sayang baik secara verbal maupun fisik.

2. Kurang meluangkan waktu yang cukup untuk anaknya.

3. Bersikap kasar secara verbal, misalnya menyindir, mengecilkan mental anak, dan berkata kasar.

4. Bersikap kasar secara fisik seperti memukul, mencubit, dan memberikan hukuman badan lainnya.

5. Terlalu memaksa anak untuk menguasai kemampuan kognitif secara dini. 
6. Tidak menanamkan good character kepada anak.

Dari hasil penelitian bahwa lingkungan sosial anak, pola asuh, dan cara mendidik anak merupakan faktorfaktor yang dapat mempengaruhi pembentukan karakter anak. Orang tua yang kurang memperhatikan anaknya, kurang mengkontrol anaknya, kurang berkomunikasi dengan anaknya serta bersikap kasar kepada anak, sangat mempengaruhi kondisi mental dari seorang anak serta pembentukan karakter anak. Faktor internal pun sangat mempengaruhi karakter dari seorang anak seperti adanya dorongan dari dalam diri anak dalam melakukan setiap tindakan yang dilakukannya.

\section{Upaya-Upaya Yang Dilakukan Oleh} Orangtua Dalam Membentuk Karakter Anak Di Era Globalisasi Di Desa Masigit Kelurahan Citangkil Kota Cilegon

Berdasarkan penelitian yang dilakukan oleh peneliti terungkap bahwa terdapat beberapa upaya yang dapat dilakukan orang tua untuk membentuk karakter anak yaitu dengan memberikan nasehat kepada anak, membiasakan anak untuk melakukan hal yang baik dan postif, memberikan contoh yang baik kepada anak. Selain itu, ketika anak melakukan kesalahan sebaiknya orantua tidak berbicara dengan perkaataan yang kasar, tidak memberikan hukuman yang berlebihan kepada anak namun harus diberikan pengertian dan arahan yang baik terhadap anak.

Selain itu dengan menerapkan pembiasaan yang baik pada anak dapat pula membentuk karakter baik pada diri anak. Anak akan merasa terbiasa dengan hal-hal yang positif apabila hal-hal positif tersebut sering dilakukan dalam kehidupan sehari-hari. Berdasarkan penelitian juga terungkap bahwa orang tua sering memberikan kesempatan kepada anak untuk mengungkapkan segala masalah atau hal apapun yang mengganjal dalam hatinya. Hal ini dilakukan agar anak merasa diperhatikan oleh orangtua dan tidak merasa sendiri ketika anak tersebut memiliki suatu persoalan. Orang tua pun bisa memberikan masukan serta nasehat kepada anak agar anak tidak melakukan hal-hal yang berdampak buruk bagi dirinya maupun lingkungan sekitarnya.

Menurut Syarbini (2014) ada tujuh metode yang harus diterapkan dalam membentuk karakter anak yaitu sebagai berikut :

1. Metode internalisasi yakni memasukkan pengetahuan dan keterampilan ke dalam diri anak agar menjadi karakternya sehari-hari. 
2. Metode keteladanan yakni pengajaran dengan cara memberikan contoh yang baik kepada anak agar ditiru.

3. Metode pembiasaan yakni membiasakan anak melakukan halhal positif di rumah, seperti mandiri, beribadah, tanggung jawab, dan sebagainya.

4. Metode bermain yakni mengalihkan rasa bosan anak terhadap keadaan tertentu dengan mengajaknya bermain permainan yang edukatif. Permainan umumnya terikat pada aturan dan ketentuan. Metode bermain menjadi salah satu alternatif bagi orangtua untuk menanamkan karakter pada anak. Tanpa mereka sadar, kegiatan bermain-main sebenarnya mengajarkan mereka karakter yang sangat penting seperti sportivitas, kerja sama, ketelitian, dan kebahagiaan.

5. Metode bercerita yakni membacakan cerita yang mengandung nilai-nilai kebaikan, seperti hikmah, heroik, dan lainnya. Ketika masih kecil, sering kali orangtua senang menceritakan sebuah dongeng kepada anaknya.

6. Metode nasihat yakni memberikan nasihat secara langsung dari hati ke hati dalam situasi yang santai tanpa anak merasa dinasihati.

7. Metode hadiah atau hukuman yakni sering mengabaikan metode reward and punishment. Orangtua memberi hukuman kepada anak ketika anak melakukan kesalahan. Namun, ketika mereka memperoleh prestasi orangtua jarang memberikan hadiah kepada anak. Hadiah bisa berupa benda, pujian, atau perbuatan seperti pelukan, mengajak liburan dan lainlain. Dalam hadiah dan hukuman, orangtua sebenarnya mengajarkan penghargaan dan tanggung jawab.

Dengan demikian, upaya yang dapat dilakukan untuk membentuk karakter anak harus dimulai dalam lingkungan keluarga. Dalam era globalisasi saat ini banyak sekali pengaruh yang datang, baik pengaruh baik maupun buruk. Orang tua harus mengajarkan nilai-nilai dan sikap yang sesuai dengan norma. Mendidik anak dilakukan dengan memberikan pengertian kepada anak mengenai hal-hal yang baik. Selain itu, orang tua juga harus memberikan pendidikan dasar dan keterampilan dasar seperti pendidika agama, sopan santun, menumbuhkan rasa kasih sayang, rasa aman, dan lain sebagainya. Ketika mendidik anak, orang tua mengedepankan nilai kasih sayang, sehingga anak menerima apa yang diajarkan oleh orang tua. 


\section{KESIMPULAN}

Kesimpulan dalam penelitian ini yaitu :

1. Orang tua memiliki peran yang sangat penting dalam pembentukan karakter anak. Orang tua merupakan pendidik pertama dan utama dalam pembentukan dan perkembangan karakter seorang anak. Orang tua memiliki peran yang paling dominan dalam membentuk karakter anak, karena orang tualah sosok yang menjadi panutan dan teladan bagi anak dan sosok yang paling dekat serta sering ditemu oleh anak. Orang tua berperan sebagai pendidik dalam keluarga adalah semua orang dewasa yang secara langsung dapat mempengaruhi pertumbuhan dan perkembangan anak di rumah. Peran orang tua bukan hanya memenihi segala kebutuhan yang diperlukan oleh anak tetapi orang tua memiliki peran untuk mengajajarkan pengetahuan, keterampilan, nilai-nilai kebaikan pada anak, mendidik, mengurus dan membesarkannya.

2. Faktor-faktor yang dapat mempengaruhi pembentukan karakter anak. Terlebih lagi di era globalisasi saat ini banyak sekali pengaruh yang datang, baik pengaruh positif maupun negatif. Faktor yang dapat mempengaruhinya yaitu faktor lingkungan tempat anak bersosialisasi yang meiliputi lingkungan keluarga, lingkungan masyarakat, dan lingkungan pergaulan anak. Selain itu faktor pola asuh dan cara mendidik merupakan faktor yang mempengaruhi pembentukan karakter anak. Orang tua yang tidak memperhatikan anaknya, bersikap kasar terhadap anak, terlalu membatasi setiap tindakan anak secara berlebihan, dan tidak menjukkan rasa kasih sayang pada anak, akan mempengaruhi karakter dari seorang anak.

3. Upaya yang dapat dilakukan dalam pembentukan karakter anak adalah dengan menerapkan hal-hal yang baik kepada anak, membiasakan anak untuk melakukan hal-hal yang postif seperti diajarkan untuk bersikap mandiri, jujur, disiplin dalam hal waktu maupun beribadah, rajin belajar maupun membantu orang tua, bersikap tanggung jawab. Memberikan nasehat kepada anak, memberikan contoh serta teladan yang baik. Mendidik anak juga harus dengan penuh perhatian dan kasih sayang.

\section{DAFTAR PUSTAKA}

Arikunto, Suharsimi. 2013. Prosedur Penelitian. Jakarta. PT. Rineka Cipta

Baharudin. 2010. Pendidikan \& Psikologi Perkembangan. Jogjakarta: ArRuzz Media.

Helmawati. (2017). Pendidikan Karakter Sehari-hari. Bandung:PT Remaja Rosdakarya.

J Moleong. Lexy. 2014. Metodologi Penelitian Kualitatif. Bandung. PT Remaja Rosdakarya

Muslich, M. 2011. Pendidikan 
Karakter:Menjawab Tantangan Krisis Multidimensional. Jakarta. Bumi aksara.

Prianti. E. Nita. 2019. Profesi Guru dan Profesionalisme Guru dalam Pembelajaran. Jakarta: PT. Raja Grafindo Persada.

Prianti. E. Nita, Laila Novia. (2019). Peran Pendidikan Pancasila dan Kewarganegaraan Dalam Menerapkan Karakter Mandiri Siswa Kelas XI IPS Madrasah Aliyah Mathla'ul Anwar Kepuh Cinangka. PRO PATRIA. 2 (1). 3037.

Syarbini, A. (2014). Model Pendidikan Karakter Dalam Keluarga.
Jakarta:Elex Media Komputindo.

Syarbini, A. (2016). Pendidikan Karakter Berbasis Keluarga (Studi Tentang Model Pendidikan Karakter Dalam Perspektif Islam). Yogyakarta : ArRuzz Media.

Toni Anwar Mahmud, Kebijakan Anggaran Pemerintah Provinsi Banten Dalam Penanganan Covid-19, Book Chapter Perguruan Tinggi Dan Dampak Pandemi, Media Madani. 2020

Coronavirus Disease (Covid-19)

Undang-Undang No. 20 Tahun 2003 Tentang Sistem Pendidikan Nasional. Bandung. Focus Media 